\title{
Effect of Adding Walnut Powder on Physical and Chemical Properties of Wheat Flour and Preventing Hyperlipidemia in Mice
}

\author{
Gill Ali Abrar', Fanrui Zhao', Hanxiong Qin'1, Ji Wang1,2, Chunlei Liu' ${ }^{1,2}$, Weihong Min ${ }^{1,2^{*}}$ \\ ${ }^{1}$ College of Food Science and Engineering, Jilin Agricultural University, Changchun, China \\ ${ }^{2}$ National Engineering Laboratory of Wheat and Corn Deep Processing, Changchun, China \\ Email: *minwh2000@jlau.edu.cn
}

How to cite this paper: Abrar, G.A., Zhao, F.R., Qin, H.X., Wang, J., Liu, C.L. and Min, W.H. (2019) Effect of Adding Walnut Powder on Physical and Chemical Properties of Wheat Flour and Preventing Hyperlipidemia in Mice. Food and Nutrition Sciences, 10, 776-792.

https://doi.org/10.4236/fns.2019.107057

Received: February 21, 2019

Accepted: July 26, 2019

Published: July 29, 2019

Copyright $\odot 2019$ by author(s) and Scientific Research Publishing Inc. This work is licensed under the Creative Commons Attribution International License (CC BY 4.0).

http://creativecommons.org/licenses/by/4.0/

(c) (i) Open Access

\begin{abstract}
Walnuts (Juglans regia L.) are naturally rich source of many important nutrients which could be helpful in different food processing. Walnut mainly containing polyunsaturated fatty acids (PUFA), especially alpha linoleic acid $(18: 3 n-3 ; 9 \mathrm{~g})$ and linoleic acid $(18: 3 \mathrm{n}-; 38 \mathrm{~g})$. Walnuts powder was fortified with commercial high gluten wheat flour (WF) into 4 composites flour from $10 \%$ to $40 \%$. Walnut flour improves the nutritional value due to high protein and fat content, but affects the technological properties. Parameters such as functional, pasting and rheological properties demonstrated the influence of walnut reincorporation into gluten network. The interaction of walnut flour with wheat flour is a key factor which effects on the dough quality, causing thinning and weakening the gluten structure. Flour with $30 \%$ to $40 \%$ walnut substitution was more nutritious especially in relation to protein and monounsaturated fatty acid (MUFA), but responsible for more changes in technological characteristics of dough. Present study was also directed to examine the effect of moderate walnut consumption on lipids profile, enzymatic anti-oxidant (superoxide dismutase SOD and glutathione peroxidase GSH-Px) and lipid peroxidation (Melondialdehyde MDA) in rats fed with high-fat food. The Sprague Dawley rats were housed for five weeks and assembled into normal, high fat, high fat $(\mathrm{HF})+10 \%$ walnut, $\mathrm{HF}+20 \%$ walnut, $\mathrm{HF}+30 \%$ walnut and $\mathrm{HF}+40 \%$ walnut. The lipid profile significantly improved especially by lowering the low-density lipoprotein cholesterol (LDL-c) and high-density lipoprotein cholesterol (HDL-c) level increased in the group of $\mathrm{HF}+40 \%$ walnut. The total anti-oxidant, SOD and GSH-Px activity were increased by supplementation of walnut and significantly higher in $\mathrm{HF}+40 \%$ compared to the normal group. The Melondialdehyde (MDA) or lipid peroxidation status was increased in $\mathrm{HF}+20 \%$ walnut to $\mathrm{HF}+30 \%$ walnut as compared to normal and HF-fed diet but reduced by HF $+40 \%$ walnut. These
\end{abstract}


results suggest that walnut intake could be effective to protect from oxidative stress by lowering the lipid peroxidation by improving antioxidant defense system in rats fed high-fat diet.

\section{Keywords}

Walnut, Pasting Properties, Rheological Properties, Lipids, Enzymatic Anti-Oxidant, Lipids Peroxidation

\section{Introduction}

Walnuts (Juglans regia L.) have different types of nutrients associated with fatty acids that differ from all other nuts, making them very special. Nuts other than walnut have more monounsaturated fatty acids (MUFA), but walnut mainly containing polyunsaturated fatty acids (PUFA), especially alpha linoleic acid and linoleic acid. Nowadays, the intake of the fatty diet which holds lower amount of bioactive components, dietary fibers and other micronutrients which is responsible for the elevation of blood pressure, diabetes, hyper cholesterol, hyperlipidemia and cardiac disorders. Ingestion of certain active ingredients, such as flavonoids, carotenoids and Glucosamine, is directly associated with decreasing the threat of hyper cholesterol, hypertension, cardiac and many other chronic diseases [1] [2].

Walnuts gain a collective interest through healthy foods because continuous ingestion declared diminish the threat of coronary heart disease [3] [4]. For this reason, walnuts can be consumed as a component of many foods, especially in baked goods to improve the nutritional and sensorial aspects of the final products [5]. Walnuts have many plant chemicals which add their overall importance related to antioxidants including melatonin, salicylic acid, vitamin E, carotenoids and polyphenols. These compounds have potential health effects on cancer, aging, inflammation and neurological disorders. Normally consumption of 6 to 7 nuts of regular size in a day can relief to remove diseases that cause free radicals in the body [6]. Organisms generate oxygen radicals by the non-enzyme and enzyme system, oxygen radicals will attack PUFA to initiate lipid peroxidation, as a result of lipid peroxides such as melondialdehyde MDA, ketone, hydroxyl, carbonyl group, and new oxygen radical generates [7]. Oxidative stress is linked with the pathogenesis of numerous chronic syndromes which shows a vital part in the aging process [8] [9]. Lipid peroxidation could also increase the effect of active oxygen by a chain and branched chain reaction. Thus, primary active oxygen can lead to many lipid decomposed products, some of them are not harmful but others can cause cellular dysmetabolism and dysfunction or even cell death. Oxygen radicals cause cell damage by not only PUFA peroxidation but also lipid hydro peroxide decomposition products. As a result, MDA content always reflects lipid peroxidation level in vivo, it can also reflect cell damage level indirectly. 
Superoxide dismutase (SOD) is an enzyme that alternately catalyzes superoxide $\left(\mathrm{O}_{2}^{-}\right)$free radicals to decompose into common molecular oxygen or hydrogen peroxide. Superoxide is produced as a by-product of oxygen metabolism and can lead to multiple types of cell damage [10]. SOD is an important antioxidant defense against all living cells exposed to oxygen. Glutathione peroxidase (GSH-Px) is a widespread, important hydrogen peroxidase in organisms. It catalyzes glutathione's reduction reaction with peroxide diagnostically leads to protection of cell structure and functions [11]. Today many developing countries facing major problem related to nutrition aspects, which leads to infant death, poor physical and mental growth of kids and low resistance to disease. Therefore, the aim of this study was to investigate the effect of walnut on enzyme antioxidant activity, lipid profile, lipid peroxidation. This study was also obtained to evaluate the pasting and rheological properties for further application in the food processing industry.

\section{Material and Methods}

\subsection{Materials and Reagents}

Raw walnuts and wheat flour were obtained from the retail outlet of Changchun, Jilin Province, China. All Diagnostic Kits were purchased from Nanjing Jiancheng Institute of Bioengineering Technology Co., Ltd. (Nanjing, China). The reagents using for all analysis were analytically graded.

\subsection{Sample Preparation}

First of all raw walnuts were entirely cleaned to take away any adhesion impurities. Then they cooked 25 - 30 minutes using stainless steel pain in order to remove the shell. The worn walnut is then cut into small pieces. A fine time was carried out in the hot water of $90^{\circ} \mathrm{C}-95^{\circ} \mathrm{C}$. Then after draining the water, the walnut is placed in air dried oven at $80^{\circ} \mathrm{C}$ for $3 \mathrm{~h}$. Then ground in (Renker, Model: GMO 1 Grinder) and screened to produce fine walnut powder and used for further analysis to check its quality properties, such as approximate composition, functional properties, paste characteristics, rheological properties and for experimental diet.

\subsection{Composites of Wheat/Walnut Flour}

For this purpose 5 flour composites were prepared with the formulation of $100 \%, 90 \%, 80 \%, 70 \%$ and $60 \%$ of wheat flour (WF) and $0,10 \%, 20 \%, 30 \%$ and $40 \%$ of walnut flour (WWF) according to [12]. All flour blends were named as WF, WWF1, WWF2, WWF3 and WWF4 respectively.

\section{Proximate Composition of Flour Blends}

The percentage of moisture, crude fat, crude fiber, protein, ash and carbohydrates of each of the flour composite was determined by using standard analytical methods according to [13]. 


\subsection{Pasting Properties}

Gelatinization attributes of flour composites were determined according to [14] by (RVA) rapid visco analyzer (Perten scientific instrument, Hagersten Sweden), with little modification. 3 gram of flour was used with 30 milliliters of deionized water every single time. Then paddle was placed in a canister holding the water with flour sample. Initial 60 seconds sample were held at $\left(50^{\circ} \mathrm{C}\right)$ and stirred at 160 round per minute the temperature was raised up to $95^{\circ} \mathrm{C}$ and heated for 3.8 minutes, after that the trial was subsequently cooled at $50^{\circ} \mathrm{C}$ for 4 minutes and held at $50^{\circ} \mathrm{C}$ intended for further 2 minutes. The paste properties of the flour samples i.e. breakdown, setback, pasting temperature, peak, final and trough viscosity were automatically recorded on the instrument's scale. All measurement was replicated thrice.

\subsection{Rheological Attributes}

During heating and subsequent cooling, a dynamic oscillation measurement of the suspension of $10 \%$ of flour and flour fractions in distilled water was carried out using the Anton Paar Rheometer (MCR 302, Anton Paar, Inc., Tru Gap ${ }^{\mathrm{TM}}$, USA). The samples were loaded between two parallel plates of $3 \mathrm{~cm}$ in diameter with $1 \mathrm{~mm}$ gap. For the prevention of samples from dehydration and insulating plate were used in foam to ease heat dissipation the sample circumference and protect with silicone oil coating. Then, the sample was started heating at the rate of $1^{\circ} \mathrm{C} / \mathrm{min}$ and frequency was set at $0.1-10 \mathrm{~Hz}$. Loss $\mathrm{G}^{\prime}$ and the storage modulus G", were constantly observed throughout the dynamic rheological testing system [15].

\subsection{Efficacy Study}

\subsubsection{Animal Care and Experimental Design}

48 male Sprague Dawley Rats of 5 weeks old (28 - 30 grams) were taken from Changchun Institute of Biological Products Co., Ltd. (license number) Scxk (Liao, 2015-0001) Changchun, China. Rat feed was purchased from Beijing Kai Cooperative Feed Co., Ltd. (license number). SCXK (Beijing) 2014-0010). The experimental study was conducted in agreement with the recommendations of the Animal Welfare Act, for the care and use of laboratory animals. The rats were randomly placed in a polypropylene cage $(320 \times 215 \times 170 \mathrm{~mm})$ with stainless steel cover and fixed under controlled conditions $22^{\circ} \mathrm{C} \pm 2{ }^{\circ} \mathrm{C}$ and relative humidity of $60 \%$, with a 12 -hour light cycle and lights were turned off at 7 $\mathrm{pm}$. In the first week, all rats were fed to their basic diet and water freely to maintain new environment.

After the first week, the rats were randomly divided into 6 sets $(n=8$ each). One group was designated as the normal group and fed its base diet another group fed a HF-diet $(\mathrm{g} / 100 \mathrm{~g})$ corn starch, 43; lard, 10; cholesterol, 1; casein, 20; cellulose, 2; vitamin mixture (ain-93; American Institute of Nutrition, Bethesda, MD), 1; sodium cholic acid, 0.20; sucrose, 20; and mineral mixtures (ain-93; American Institute of Nutrition), 3.5. The other four groups received the same 
(HF) diet, but increased by $10 \%-40 \%$ walnut solution $1 \mathrm{ml} / 100 \mathrm{~g}$ of body weight by oral gavage. The physiological saline solution was given with the rate of 1 $\mathrm{ml} / 100 \mathrm{~g}$ of body weight by oral gavage on daily basis to the animals of normal and HF groups. Animals were housed for 35 days under controlled conditions and body weight gain were collected on a weekly basis.

\subsubsection{Tissue and Blood Collection}

After the 35 days of trial blood samples were collected after $24 \mathrm{~h}$ of starved time and rats were killed after blood collection immediately with cervical dislocation. After the collection of blood, the serum was separated by centrifugation at 3500 rpm for 10 minutes. All body organs were also collected to check their organ weights. Then the separated blood serum, liver and brain tissue were stored at $-20^{\circ} \mathrm{C}$ for further analysis.

\subsubsection{Serum Lipid Profile}

For analysis of serum total cholesterol (TC) values of rats were measured using the CHOD-PAP method according to [16]. Triglycerides (TG) in serum were calculated by liquid triglycerides (GPO-PAP) method followed by [17]. The absorbance values were measured at $510 \mathrm{~nm}$. LDL-C, and HDL-C were detected by using commercial kits and absorbance was read at $546 \mathrm{~nm}$ according to the company's instructions.

\subsubsection{Liver Lipid Profile}

For liver lipid profile analysis tissue, $1 \mathrm{~g}$ sample was weighed precisely and add 9 $\mathrm{ml}$ homogenate medium (absolute alcohol) at the ratio of 1:9 to make $10 \%$ (volume/volume). The homogenate medium was mixed with tissue sample in an ice water bath. Then homogenate solution was treated with centrifugation at 2500 rpm for 10 minutes at $4^{\circ} \mathrm{C}$ and supernatant was extracted for use. The HDL-C, LDL-C, TC and TG in the supernatant were measured using commercial kits according to the company's instructions.

\subsubsection{Total Antioxidant Activity}

Total antioxidant activities (T-AOC) of blood serum, liver and brain tissue were measured by 2,2'-azino-bis(3-ethylbenzothiazoline-6-sulphonic acid) using (A015-2, ABTS) commercial kit according to the company's guidelines. The results were expressed in $\mathrm{mM}$ and $\mathrm{mM} / \mathrm{mg}$ protein on blood serum and tissue homogenate respectively against the Trolox standard curve.

\subsubsection{Determination of Enzyme Antioxidant Activity}

GSH-Px and SOD activities of blood serum, brain and liver homogenate $(10 \%$ $\mathrm{v} / \mathrm{v}$ ) were measured using commercial kits (A001-3 Wst-1 and A005) colorimetric methods respectively of according to assay protocol. Results were expressed in $(\mathrm{U} / \mathrm{ml}$ and $\mathrm{U} / \mathrm{mg}$ protein) for blood serum and tissue homogenate respectively. When the SOD inhibition percentage ranges to 50 percent during the reaction system, then coenzyme capacity could be considered as 1 SOD activity unit (U). 
GSH-Px active site is Se-cysteine, selenium is a necessary part of GSH-Px, and 1 mol GSH-Px contains $4 \mathrm{~g}$ selenium.

\subsubsection{Lipids Peroxidation/Melondialdehyde (MDA) Assay}

Lipid peroxidation was analyzed with the amount of thiobarbituric acid reactive substances (TBARS) by using commercial kit (A003-1) according to the company's guidelines with (TBA) method. The results of MDA were expressed in $\mathrm{nmol} / \mathrm{ml}$ for blood serum and nmol/mg protein of liver and brain tissue homogenate.

\subsection{Statistical Analysis}

To determine the least significant difference $(\mathrm{p}<0.05)$ the data of all parameters were subjected to statistical analysis. All results were expressed by using analytical software statistics 8 version 8.1 (Analytical Software, Tallahassee, USA), and analysis of variance (ANOVA) was performed. The graphical results were expressed by using statistical software of origin pro 8.5.0 SRI (Origin lab cooperation, Northampton, MA 01060, USA).

\section{Results and Discussion}

Physico-chemical properties: The statistical data of composite flour are presented in Table 1. Moisture content ranged from 5.63\% - 9.13\%. According to [6] usually moisture content of dried food/flour blends should not be exceeded to $9 \%$. Consider when flour and starch-containing samples having more than $12 \%$ moisture content, storage ability will be reduced related to those who have less moisture. Flour and flour-related products overall show longer and safe shelf life with $10 \%$ moisture content. The maximum moisture content was witnessed in (WWF3) and significantly differed ( $<$ 0.05) from all other samples. Different food commodities have different properties for retaining moisture which may occur as absorbed or blocked water [18]. Thus the addition of walnut flour with wheat flour reduced the moisture content of the composite flour samples and bind the moisture level. The crude protein content in flour composites were ranged from $11.203 \%-23.24 \%$ and shows statistically significant result at ( $\mathrm{p}<$ 0.05). The highest protein content (23.24\%) were present in WWF4, whereas the

Table 1. Physico-chemical composition of flour composites.

\begin{tabular}{ccccccc}
\hline Code & Moisture (\%) & $\begin{array}{c}\text { Crude } \\
\text { Protein (\%) }\end{array}$ & $\begin{array}{c}\text { Crude Fat } \\
(\%)\end{array}$ & $\begin{array}{c}\text { Crude Ash } \\
(\%)\end{array}$ & $\begin{array}{c}\text { Crude Fiber } \\
(\%)\end{array}$ & CHO (\%) \\
\hline WF & $8.12^{\mathrm{ab}} \pm 0.4$ & $11.2^{\mathrm{e}} \pm 0.08$ & $1.48^{\mathrm{e}} \pm 0.13$ & $2.27^{\mathrm{b}} \pm 0.1$ & $10.9^{\mathrm{a}} \pm 0.65$ & $65.9^{\mathrm{b}} \pm 1.1$ \\
WWF1 & $5.63^{\mathrm{b}} \pm 0.2$ & $12.21^{\mathrm{d}} \pm 0.2$ & $8.69^{\mathrm{d}} \pm 0.2$ & $1.22^{\mathrm{c}} \pm 0.13$ & $1.76^{\mathrm{e}} \pm 0.24$ & $70.46^{\mathrm{a}} \pm 0.5$ \\
WWF2 & $6.3^{\mathrm{d}} \pm 0.10$ & $17.27^{\mathrm{c}} \pm 0.3$ & $14.7^{\mathrm{c}} \pm 0.23$ & $2.18^{\mathrm{b}} \pm 0.2$ & $2.7^{\mathrm{d}} \pm 0.19$ & $56.74^{\mathrm{c}} \pm 0.2$ \\
WWF3 & $9.13^{\mathrm{a}} \pm 0.32$ & $19.33^{\mathrm{b}} \pm 0.2$ & $23.6^{\mathrm{b}} \pm 0.1$ & $3.24^{\mathrm{a}} \pm 0.81$ & $3.82^{\mathrm{c}} \pm 0.22$ & $40.8^{\mathrm{d}} \pm 0.8$ \\
WWF4 & $7.07^{\mathrm{c}} \pm 0.18$ & $23.24^{\mathrm{a}} \pm 0.2$ & $24.5^{\mathrm{a}} \pm 0.21$ & $1.22^{\mathrm{c}} \pm 0.25$ & $4.8^{\mathrm{b}} \pm 0.06$ & $39.06^{\mathrm{e}} \pm 0.1$ \\
\hline
\end{tabular}

All values are means \pm standard deviation with triplicate determination, Values presented in the same column with different superscript are statistically significant with each other at $(p \leq 0.05)$. 
minimum crude protein content (11.203\%) observed in WF. These findings were not surprising because the percentage of protein content in the walnut seed of dry weight basis contain $18 \%$ - 24\% [19]. According to results finding a more shelf stable product due to lower moisture level while protein content increasing significantly and the objective of flour fortification was achieved [20].

The crude fat content ranged from $1.48 \%-24.5 \%$, sample with (WF) flour composite had minimum fat content (1.48\%), while the highest fat $(24.5 \%)$ observed in (WWF4). Walnuts have PUFA which helps healthful, the increasing fat content is due to high \% of oil in walnut flour. Rancidity due to the presence of oil in walnut and wheat flour composites may cause a problem in storage condition [21]. Therefore, proper storage will be needed to avoid the rancidity factor and retain longer shelf life of food commodities. The ash content within flour composites were ranged from $1.22 \%-3.247 \%$. The ash content was increasing with the substitution of walnut powder from $20 \%-40 \%$, while ash content was reduced with the addition of 10 percent walnut flour with wheat flour. Sample (WWF3) shows statistically significant result from other samples at $(\mathrm{p}<0.05)$ due to the maximum crude ash content (3.24\%), samples (WF and WWF2) were statistically not significant from each other, however, samples (WWF1 and WWF4) also not have any significant difference $(p>0.05)$ from each other.

The percentage of crude fiber content in flour composites ranged from 1.76 10.9\%. The highest fiber content was observed in WF (10.9\%). Fiber content was decreased surprisingly with $10 \%$ fortification of walnut flour, then it tended to improve from $20 \%$ to $40 \%$ of walnut flour fortification. The results were statistically significant among all samples at $0.05 \%$. The amount of carbohydrate ( $\mathrm{CHO} \%$ ) content ranged from $39.06 \%$ to $70.46 \%$. The results of carbohydrate content of all 5 samples were statistically significant at $(\mathrm{p}<0.05)$. Sample WWF1 shows the maximum amount of carbohydrate content of $70.46 \%$. The $\mathrm{CHO} \%$ was correspondingly decreased with the addition of walnut powder into wheat flour. It has been also discussed in the previous study [22] who conclude that carbohydrate reduced while increasing the addition of soybean flour in wheat flour fortification.

Pasting Properties: The pasting properties are a key factor in predicting the capacity of the flour samples and pasting performance. The results of pasting properties are shown in Table 2 obtained by RVA. The highest values of peak viscosity, trough, breakdown, final viscosity and setback were recorded in WF and lowest in WWF4 followed by WWF3. All values for peak viscosity, trough, breakdown, final viscosity and setback were significantly different from each other at $(\mathrm{p} \leq 0.05)$. According to the results reported pasting parameters were decreased with the increase in addition of walnut flour. The viscosity of all sample was graphically presented against heating time in seconds (Figure 1). Pasting properties disturbing against different composite flours could be due to the difference in starch composition and connection among the structure [23].

Rheological Attributes: A unique viscoelastic material called dough was formed after mixing flour and water. By the frequency sweep tests the excellence 
Table 2. Pasting properties of flour samples.

\begin{tabular}{cccccccc}
\hline Code & PV $(\mathrm{cp})$ & Trough $(\mathrm{cp})$ & BD $(\mathrm{cp})$ & FV $(\mathrm{cp})$ & Setback & PT $(\mathrm{min})$ & PTT $\left({ }^{\circ} \mathrm{C}\right)$ \\
\hline WF & $2118.7^{\mathrm{a}} \pm 212.4$ & $1472.3^{\mathrm{a}} \pm 159.1$ & $646.3^{\mathrm{a}} \pm 82.7$ & $2648^{\mathrm{a}} \pm 195.4$ & $1175.7^{\mathrm{a}} \pm 64.5$ & $6.15^{\mathrm{a}} \pm 0.13$ & $69.26^{\mathrm{bc}} \pm 0.8$ \\
WWF1 & $1185.7^{\mathrm{b}} \pm 153$ & $655.3^{\mathrm{b}} \pm 112.95$ & $530.3^{\mathrm{b}} \pm 41.4$ & $1423^{\mathrm{b}} \pm 195.1$ & $767.6^{\mathrm{b}} \pm 82.5$ & $5.6^{\mathrm{b}} \pm 0.13$ & $79.56^{\mathrm{abc}} \pm 8.9$ \\
WWF2 & $765.67^{\mathrm{c}} \pm 28.18$ & $365.6^{\mathrm{c}} \pm 13.65$ & $400^{\mathrm{c}} \pm 18.6$ & $867.3^{\mathrm{c}} \pm 24$ & $501.6^{\mathrm{c}} \pm 10.4$ & $5.26^{\mathrm{c}} \pm 0.06$ & $85.26^{\mathrm{ab}} \pm 0.9$ \\
WWF3 & $503^{\mathrm{d}} \pm 18.6$ & $226.3^{\mathrm{cd}} \pm 11.01$ & $276.6^{\mathrm{d}} \pm 8.1$ & $544^{\mathrm{d}} \pm 27.1$ & $317.6^{\mathrm{d}} \pm 16.4$ & $5.11^{\mathrm{c}} \pm 0.03$ & $86.95^{\mathrm{a}} \pm 0.4$ \\
WWF4 & $309.3^{\mathrm{d}} \pm 23$ & $148.3^{\mathrm{d}} \pm 4.04$ & $161^{\mathrm{e}} \pm 19.5$ & $313.3^{\mathrm{e}} \pm 14.6$ & $165^{\mathrm{e}} \pm 11$ & $5.06^{\mathrm{c}} \pm 0.2$ & $67.03^{\mathrm{c}} \pm 18.1$ \\
\hline
\end{tabular}

PV-peak viscosity, BD-breakdown, FV-final viscosity, PT-peak time, PTT-pasting temperature; All values are means \pm standard deviation with triplicate determination, Values of each column with different superscript are significant with each other at $(\mathrm{p} \leq 0.05)$.

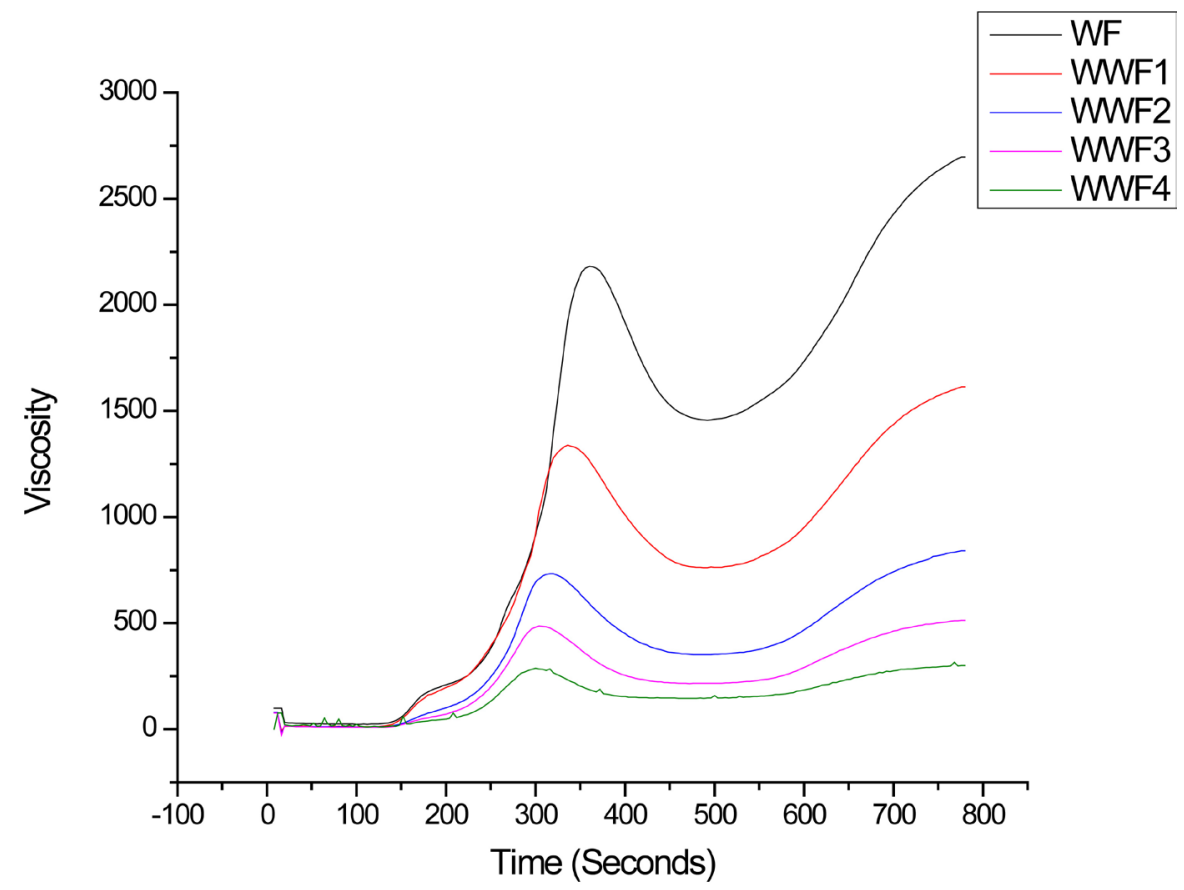

Figure 1. Comparative impact of heating time on the viscosity of all flour samples.

and process-capability of dough for all 5 flour composites was studied. The variations of loss, storage modulus, and tan delta were shown in Figures 2-4 respectively. Storage $\left(G^{\prime}\right)$ and loss modulus $\left(G^{\prime \prime}\right)$ of flour composites were ranged 474 6380 and 72.4 - 1410 respectively, however the highest $G^{\prime}$ and $G^{\prime \prime}$ was observed in WF followed by WWF1.

The lowest values of G' and G" was observed in WWF4, whereas the tan delta (G"/G') of WWF3 was slightly lower. The G' and G" decreased with the increase in walnut flour substitution and increased with increasing frequency rate. For the development of better/dough and good quality product, rheological behavior of the flour is the important and dynamic factor. In the conclusion dough of WF sample shows more elastic performance at higher frequency rate and storage modulus is always higher than loss modulus. Mainly starch-bound proteins and lipids act as surfactants involved in dough mixing. High G' and G" could be due the less amount of water content in the flour which is a key factor for the formation of 
dough, thereby lack of lubricating agent for interaction resulted in higher storage and loss modulus while lowering the tan delta [24]. According to past agreement [25], starch granules can influence the rheology of dough and flour baking feature.

Body weight gain: Animals fed with HF showed maximum weight gain on a weekly basis, whereas decreased with increasing walnut consumption. The results of body weight gain expressed in Table 3 . The data were not significantly

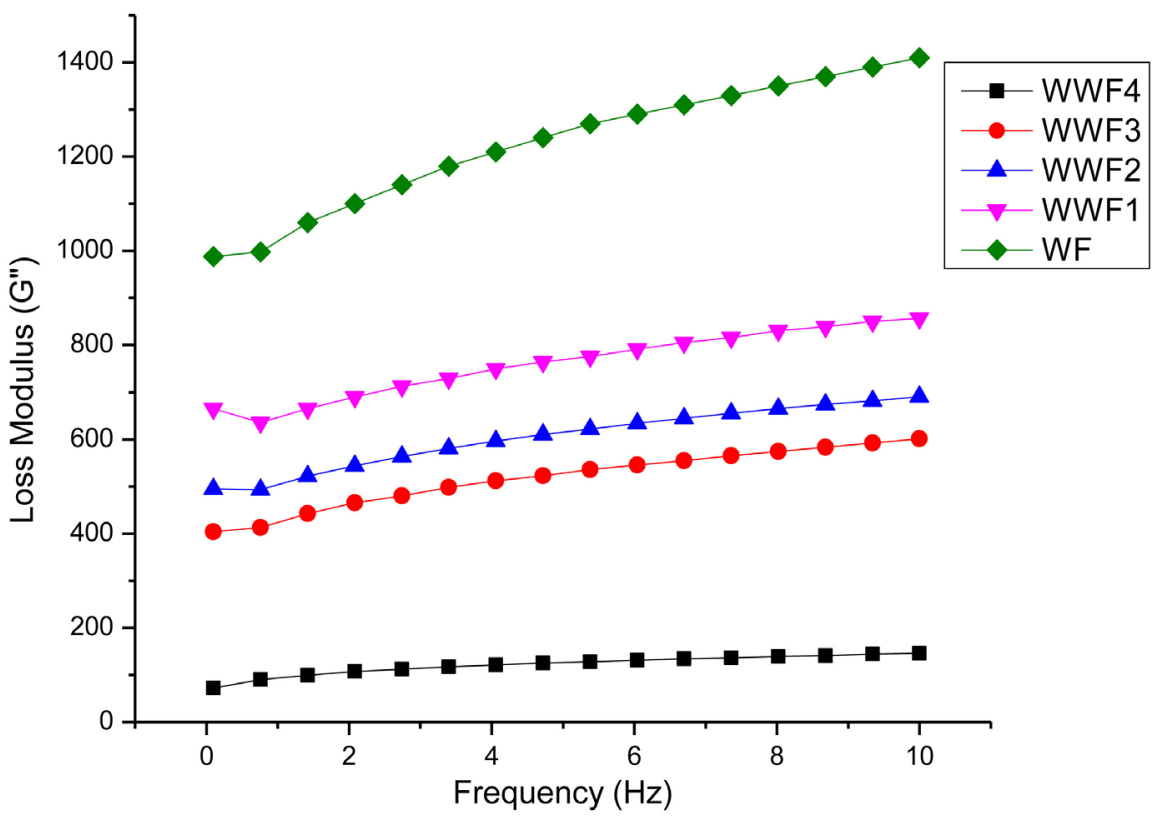

Figure 2. Loss modulus $\left(G^{\prime \prime}\right)$ values generated during heating of wheat flour and walnut/wheat flour fractions.

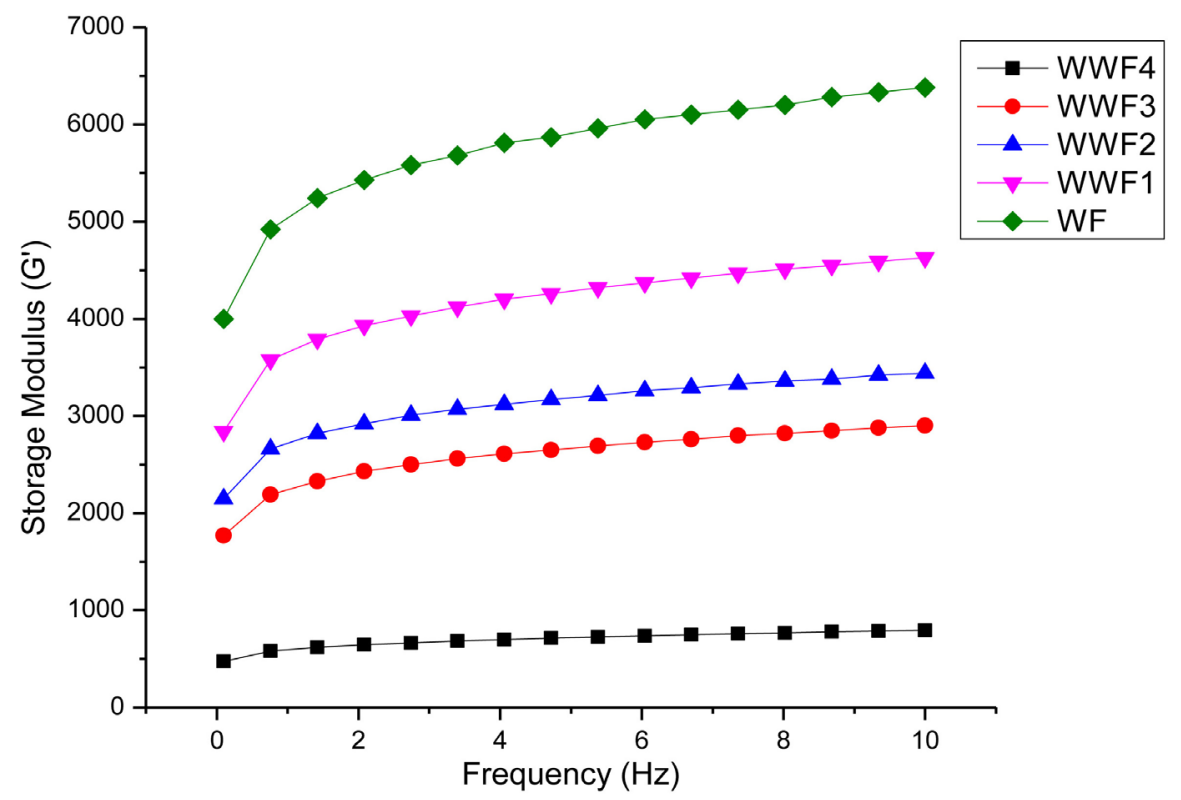

Figure 3. Storage modulus $\left(G^{\prime}\right)$ values generated during heating of wheat flour and walnut/wheat flour fractions. 


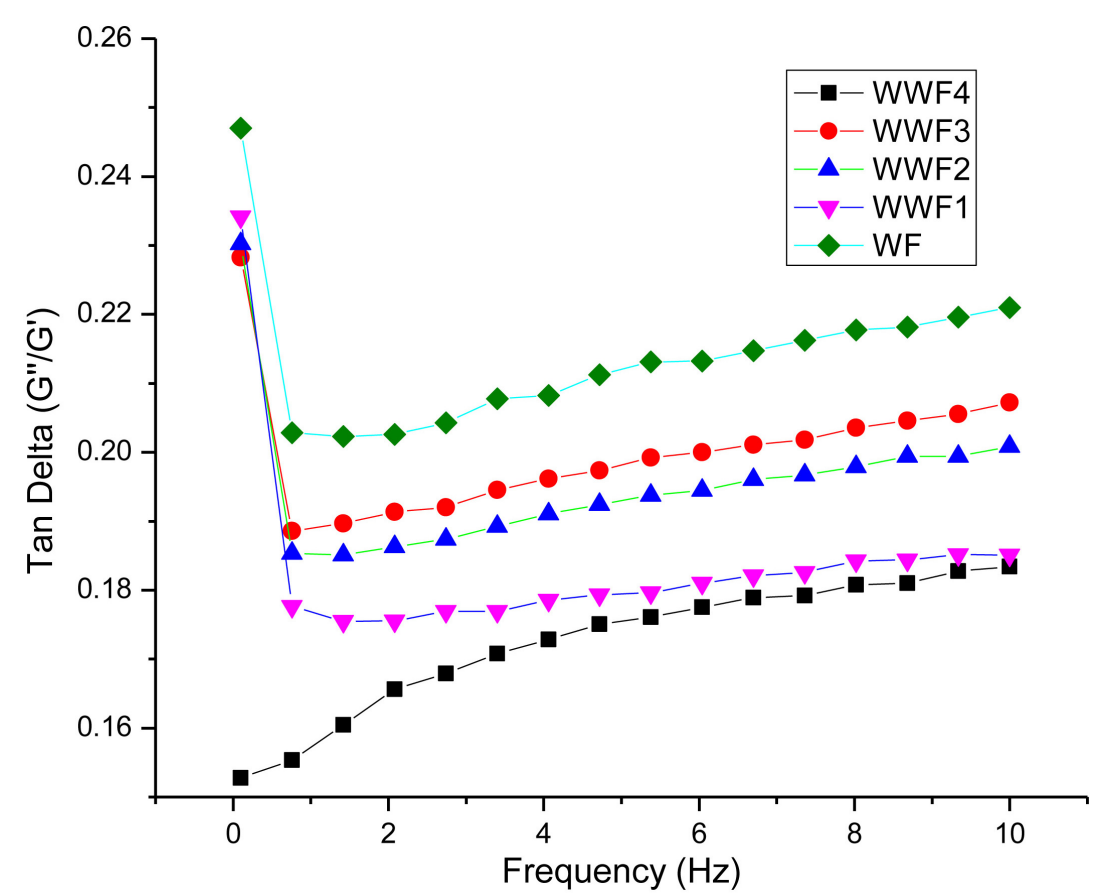

Figure 4. Tan delta $\left(\mathrm{G}^{\prime \prime} / \mathrm{G}^{\prime}\right)$ values generated by dividing loss modulus with storage modulus.

Table 3. Animal weekly body weight gain and organ weight after 35 days of trail.

\begin{tabular}{ccccccc}
\hline & Normal & HF & HF $+10 \%$ walnut & HF $+20 \%$ walnut & HF $+30 \%$ walnut & HF $+40 \%$ walnut \\
\hline Initial Weight (g) & $30.5^{\mathrm{a}} \pm 2.2$ & $32.3^{\mathrm{a}} \pm 1$ & $31.35^{\mathrm{a}} \pm 1.7$ & $31.75^{\mathrm{a}} \pm 0.9$ & $31.19^{\mathrm{a}} \pm 1.4$ & $31.9^{\mathrm{a}} \pm 2.1$ \\
After first week & $6.62^{\mathrm{a}} \pm 4.7$ & $5.17^{\mathrm{ab}} \pm 5.4$ & $3.19^{\mathrm{ab}} \pm 6.1$ & $0.64^{\mathrm{ab}} \pm 6.7$ & $-3.1^{\mathrm{b}} \pm 11.4$ & $1.24^{\mathrm{ab}} \pm 6.8$ \\
After second week (\%) & $13.8^{\mathrm{a}} \pm 11.7$ & $11.0^{\mathrm{a}} \pm 5.7$ & $10.2^{\mathrm{a}} \pm 13.0$ & $4.80^{\mathrm{a}} \pm 6.9$ & $2.47^{\mathrm{a}} \pm 13.2$ & $8.87^{\mathrm{a}} \pm 6.3$ \\
After third week (\%) & $21.55^{\mathrm{a}} \pm 9.3$ & $19.8^{\mathrm{a}} \pm 5.7$ & $10.6^{\mathrm{a}} \pm 18.4$ & $10.34^{\mathrm{a}} \pm 6.9$ & $8.7^{\mathrm{a}} \pm 11.69$ & $14.25^{\mathrm{a}} \pm 5.7$ \\
After four week (\%) & $23.8^{\mathrm{ab}} \pm 7.6$ & $28.7^{\mathrm{a}} \pm 4.2$ & $13.4^{\mathrm{b}} \pm 19.3$ & $14.8^{\mathrm{b}} \pm 5.16$ & $14.24^{\mathrm{b}} \pm 9.5$ & $16.7^{\mathrm{ab}} \pm 6.9$ \\
After five week (\%) & $24.6^{\mathrm{ab}} \pm 11.1$ & $33.7^{\mathrm{a}} \pm 3.6$ & $22.4^{\mathrm{ab}} \pm 13.9$ & $21.1^{\mathrm{ab}} \pm 6.2$ & $20.02^{\mathrm{b}} \pm 10.3$ & $22.7^{\mathrm{ab}} \pm 9.7$ \\
Liver (g) & $1.37^{\mathrm{b}} \pm 0.1$ & $1.60^{\mathrm{a}} \pm 0.1$ & $1.5^{\mathrm{ab}} \pm 0.07$ & $1.5^{\mathrm{ab}} \pm 0.07$ & $1.41^{\mathrm{b}} \pm 0.22$ & $1.4^{\mathrm{ab}} \pm 0.05$ \\
Heart (g) & $0.19^{\mathrm{ab}} \pm 0.02$ & $0.21^{\mathrm{a}} \pm 0.03$ & $0.20^{\mathrm{ab}} \pm 0.02$ & $0.20^{\mathrm{ab}} \pm 0.01$ & $0.17^{\mathrm{b}} \pm 0.01$ & $0.19^{\mathrm{ab}} \pm 0.03$ \\
Kidney (g) & $0.45^{\mathrm{a}} \pm 0.05$ & $0.50^{\mathrm{a}} \pm 0.05$ & $0.48^{\mathrm{a}} \pm 0.05$ & $0.47^{\mathrm{a}} \pm 0.04$ & $0.45^{\mathrm{a}} \pm 0.03$ & $0.44^{\mathrm{a}} \pm 0.06$ \\
Brain (g) & $0.28^{\mathrm{ab}} \pm 0.03$ & $0.19^{\mathrm{b}} \pm 0.04$ & $0.30^{\mathrm{ab}} \pm 0.05$ & $0.31^{\mathrm{a}} \pm 0.08$ & $0.32^{\mathrm{a}} \pm 0.13$ & $0.34^{\mathrm{a}} \pm 0.11$ \\
Spleen (g) & $0.11^{\mathrm{a}} \pm 0.02$ & $0.15^{\mathrm{a}} \pm 0.03$ & $0.14^{\mathrm{a}} \pm 0.04$ & $0.14^{\mathrm{a}} \pm 0.03$ & $0.13^{\mathrm{a}} \pm 0.05$ & $0.10^{\mathrm{a}} \pm 0.04$ \\
\hline
\end{tabular}

Mean \pm Standard deviation $(n=6)$ values with the different superscripts within the row were significant at $(\mathrm{p} \leq 0.05)$.

differed from each other, but the overall group of HF-diet gain more body weight compared to others and showed significantly differed at $(p \leq 0.05)$. [26] reported that there is no effect in body weight on the basis of short-term walnut consumption. However, in [27] [28] reported that loss in weight could be due to the increasing of walnut consumption.

Organs Weight: Results of organ weight have been presented in Table 3. Animal fed with HF show maximum liver weight $(1.603 \mathrm{~g})$ and lowermost weight was observed in a normal group of animals $(1.37 \mathrm{~g})$. Animals fed with normal diet and 
HF-diet along with $30 \%$ walnut meal were shown non-significant result. Meanwhile, the animals fed with HF-diet along with $10 \%, 20 \%$ and $40 \%$ walnut meal were also non-significant from each other and significantly differed ( $p \leq 0.05$ ) from other groups. The present results indicate the liver weight was significantly increased with a HF-diet which the agreement of [29] as compared to the animals those who were treated with their normal diet. It can also be observed that the animals fed with HF-diet along with walnut meal were also given the lowest weight of the liver. Heart weight of HF rats was also reported high $(0.218 \mathrm{~g})$, however, lowest weight was observed in HF-diet along with 30\% walnut meal and showed significant different result $(\mathrm{p} \leq 0.05)$ from all other groups. The results indicate that the weight of liver and heart of HF fed animals decreased with increasing the percentage of walnut meal. It could be due to deposition of lipids especially saturated fatty acids (SFAs) in HF-diet. Whereas no significant difference ( $\mathrm{p} \leq 0.05)$ in kidney and spleen weight. The weight of the brain of HF rats was observed less $(0.195 \mathrm{~g})$ and highest in $40 \%$ walnut consumption (0.346 g) followed by $30 \%$ walnut meal $(0.326 \mathrm{~g})$. The weight of brain was increased with the increasing the intake of walnut in HF-fed animals. This could be due to the abundant amount of Omega- 6 and saturated fats together with unsaturated fatty acids which affect the blood circulation towards the brain and leads to the hardening of the arteries. It could also increase the risk of an ischemic stroke.

Serum lipid profile: TC, LDL-C, TG and HDL-C levels shown in Table 4. TC in animals of HF supplement with $1 \%$ cholesterol in the food was higher expectedly compared to other groups who fed with walnuts of different composition. Lower levels of TC, LDL-C and TG were observed in animal fed with $40 \%$ walnut followed by $30 \%$ walnut at $(\mathrm{p} \leq 0.05)$. LDL-C and TG showed significant difference ( $\mathrm{p} \leq 0.05$ ) between the HF and other 5 groups, however, lower values were observed in normal and $40 \%$ walnut consumption groups respectively. While HDL-C was increased significantly in $40 \%$ walnut fed animals followed by $30 \%$ walnut consumption. The subject in the normal group showed low value of

Table 4. Lipid profile of blood serum and liver.

\begin{tabular}{ccccccc}
\hline Blood serum (mmol/l) & Normal & HF & HF $+10 \%$ walnut & HF $+20 \%$ walnut & HF $+30 \%$ walnut & HF $+40 \%$ walnut \\
LDL-C & $0.45^{\mathrm{b}} \pm 0.09$ & $1.27^{\mathrm{a}} \pm 1$ & $0.64^{\mathrm{b}} \pm 0.14$ & $0.62^{\mathrm{b}} \pm 0.18$ & $0.60^{\mathrm{b}} \pm 0.09$ & $0.59^{\mathrm{b}} \pm 0.19$ \\
HDL-C & $0.97^{\mathrm{c}} \pm 0.15$ & $1.09^{\mathrm{c}} \pm 0.19$ & $1.21^{\mathrm{c}} \pm 0.27$ & $1.40^{\mathrm{c}} \pm 0.17$ & $2.15^{\mathrm{b}} \pm 0.64$ & $3.02^{\mathrm{a}} \pm 0.87$ \\
T-CHO & $4.10^{\mathrm{b}} \pm 0.45$ & $6.33^{\mathrm{a}} \pm 0.84$ & $6.44^{\mathrm{a}} \pm 0.96$ & $5.93^{\mathrm{a}} \pm 0.89$ & $4.78^{\mathrm{b}} \pm 0.58$ & $4.30^{\mathrm{b}} \pm 0.79$ \\
TG & $0.75^{\mathrm{b}} \pm 0.38$ & $1.32^{\mathrm{a}} \pm 0.19$ & $0.91^{\mathrm{b}} \pm 0.13$ & $0.83^{\mathrm{b}} \pm 0.14$ & $0.86^{\mathrm{b}} \pm 0.16$ & $0.65^{\mathrm{b}} \pm 0.31$ \\
Liver (mmol/mg prot) & & & & & & $0.7 .37^{\mathrm{bc}} \pm 0.17$ \\
LDL-C & $2.60^{\mathrm{b}} \pm 0.7$ & $4.31^{\mathrm{a}} \pm 1.89$ & $2.40^{\mathrm{b}} \pm 0.32$ & $1.91^{\mathrm{b}} \pm 0.24$ & $0.751^{\mathrm{c}} \pm 0.6$ \\
HDL-C & $6.34^{\mathrm{c}} \pm 0.95$ & $6.06^{\mathrm{c}} \pm 1.46$ & $7.28^{\mathrm{bc} \pm 1.11}$ & $9.17^{\mathrm{abc}} \pm 3.2$ & $12.01^{\mathrm{a}} \pm 3.8$ & $9.87^{\mathrm{ab}} \pm 2.75$ \\
T-CHO & $11.67^{\mathrm{c}} \pm 2.9$ & $20.1^{\mathrm{a}} \pm 2.56$ & $17.9^{\mathrm{ab}} \pm 3.3$ & $15.6^{\mathrm{b}} \pm 0.38$ & $16.8^{\mathrm{ab}} \pm 4.39$ & $10.6^{\mathrm{c}} \pm 2.15$ \\
TG & $8.4^{\mathrm{c}} \pm 1.72$ & $13.08^{\mathrm{a}} \pm 2.1$ & $12.26^{\mathrm{a}} \pm 2.4$ & $11.45^{\mathrm{ab}} \pm 1.4$ & $9.67^{\mathrm{bc}} \pm 1.6$ & $8.71^{\mathrm{c}} \pm 2.02$ \\
\hline
\end{tabular}

Mean \pm Standard deviation $(n=6)$ result with the different superscripts in each row were statistically significant at $(\mathrm{p} \leq 0.05)$. 
HDL-C ( $p \leq 0.05)$ than HF group. Due to a high ratio of alpha-linolenic acid and linoleic acid, it could play a major role in decreasing the LDL-C and lowering the threat of coronary heart diseases.

Liver lipid profile: The statistical data of TC, LDL-C, HDL-C and TG were shown in Table 4. Rats fed with HF-diet observe the highest amount of TC, LDL-C and TG compared to the normal group. The values of TC, LDL-C and TG were decreased with increasing walnut consumption from $10 \%-40 \%$. The lowest level of LDL-C was obtained in $40 \%$ walnut consumption followed by $30 \%$ and showed significant difference from other groups at $(\mathrm{p} \leq 0.05)$. HDL-C levels were not significantly different in normal and HF fed animal, meanwhile animal fed by $30 \%$ walnut diet along with HF-diet showed the highest level and the results significantly differed from other groups at $(p \leq 0.05)$. The present study concludes and meets with the agreement of previous findings that positive effects of walnut ingestion on lipid profile [30] [31]. High levels of TC in HF-diet could be due to high content of saturated fatty acid and seems to be lipid deposition in liver tissue. Excessive lipid deposition in the liver leads to the steatosis and source of disproportion in triacylglycerol synthesis in liver and its secretion [32].

Total Anti-oxidant Capacity (T-AOC): The T-AOC values of rat's blood serum, liver and brain tissue has been listed in Table 5 . In blood serum and liver, the rats fed with $\mathrm{HF}$ along with $40 \%$ walnut consumption showed the highest T-AOC, however, the lowest value was observed in HF fed rats and significant from each other at $(\mathrm{p} \leq 0.05)$. The groups of normal diet and HF-diet along with $10 \%-30 \%$ walnut consumption were showed significant difference to each other at ( $\mathrm{p} \leq 0.05)$, however significant to other groups (HF-diet and $40 \%$ walnut consumption). Rats fed with $40 \%$ walnut along with HF-diet were also reported a maximum amount of T-AOC in (Serum, Liver and Brain). In conclusion

Table 5. Total anit-oxidant and enzymatic anit-oxidant (SOD and GSH-Px) in blood, liver and brain.

\begin{tabular}{|c|c|c|c|c|c|c|}
\hline Blood serum & Normal & $\mathrm{HF}$ & $\mathrm{HF}+10 \%$ walnut & $\mathrm{HF}+20 \%$ walnut & $\mathrm{HF}+30 \%$ walnut & $\mathrm{HF}+40 \%$ walnut \\
\hline Total anti-oxidant (mM/l) & $0.83^{\mathrm{ab}} \pm 0.02$ & $0.77^{\mathrm{c}} \pm 0.04$ & $0.79^{b c} \pm 0.04$ & $0.82^{\mathrm{bc}} \pm 0.005$ & $0.83^{\mathrm{ab}} \pm .007$ & $0.87^{\mathrm{a}} \pm 0.06$ \\
\hline $\mathrm{SOD}(\mathrm{U} / \mathrm{ml})$ & $56.3^{\mathrm{bc}} \pm 8.03$ & $50.2^{\mathrm{c}} \pm 6.2$ & $57.66^{\mathrm{bc}} \pm 12.1$ & $60.12^{\mathrm{abc}} \pm 6.3$ & $66.24^{\mathrm{ab}} \pm 9.9$ & $71.08^{\mathrm{a}} \pm 6.6$ \\
\hline GSH-Px (U) & $334.4^{\mathrm{b}} \pm 44.1$ & $266.6^{c} \pm 43$ & $256.9^{\mathrm{cd}} \pm 36.7$ & $244.6^{\mathrm{cd}} \pm 39.1$ & $205.8^{\mathrm{d}} \pm 52.4$ & $399.1^{\mathrm{a}} \pm 50.2$ \\
\hline \multicolumn{7}{|l|}{ Liver } \\
\hline Total anti-oxidant (mM/mg protein) & $30.1^{\mathrm{ab}} \pm 3.4$ & $26.8^{\mathrm{b}} \pm 4.7$ & $29.02^{\mathrm{ab}} \pm 4.5$ & $28.13^{\mathrm{ab}} \pm 2.5$ & $30.8^{\mathrm{ab}} \pm 3.8$ & $33.09^{\mathrm{a}} \pm 5.6$ \\
\hline SOD (U/mg protein) & $195.2^{\mathrm{d}} \pm 44$ & $227.4^{\mathrm{cd}} \pm 44$ & $292^{\mathrm{abc}} \pm 82$ & $261^{\mathrm{bcd}} \pm 42.9$ & $332.9^{\mathrm{ab}} \pm 67.6$ & $341.3^{\mathrm{a}} \pm 49$ \\
\hline GSH-Px (U) & $241^{\mathrm{d}} \pm 10.4$ & $474.4^{\mathrm{c}} \pm 22$ & $461.7^{c} \pm 25.1$ & $480.8^{\mathrm{c}} \pm 11$ & $542.3^{\mathrm{b}} \pm 28$ & $613.6^{\mathrm{a}} \pm 23.8$ \\
\hline \multicolumn{7}{|l|}{ Brain } \\
\hline SOD (U/mg protein) & $100.8^{\mathrm{b}} \pm 20$ & $105.8^{\mathrm{b}} \pm 31$ & $124.8^{\mathrm{ab}} \pm 21.1$ & $127.7^{\mathrm{ab}} \pm 44$ & $133.5^{\mathrm{ab}} \pm 14.8$ & $164.9^{a} \pm 42.2$ \\
\hline GSH-Px (U) & $24.03^{\mathrm{d}} \pm 8.2$ & $25.6^{\mathrm{d}} \pm 11.4$ & $68.31^{c} \pm 13.3$ & $107.4^{\mathrm{ab}} \pm 11$ & $95.52^{\mathrm{b}} \pm 8.2$ & $117.4^{\mathrm{a}} \pm 12.6$ \\
\hline
\end{tabular}

Mean \pm Standard deviation $(n=6)$ values with the different superscripts with in the row were significant at $(\mathrm{p} \leq 0.05)$. 
to the above outcomes indicated that walnut consumption could contribute the anti-oxidant capacity [33] [34] compared to other nuts, walnuts have a good source of polyphenols and the least amount of vitamins $\mathrm{E}$.

Enzyme anti-oxidant activity: SOD and GSH-Px activity of rat blood serum, liver and brain shown in Table 5. Animals fed by HF-diet along with $40 \%$ walnut consumption SOD activity observed the highest amount $(71.08 \mathrm{U} / \mathrm{ml}, 341.31$ $\mathrm{U} / \mathrm{mg}$ protein, $164.92 \mathrm{U} / \mathrm{mg}$ protein) in blood serum, liver and brain. The lowest amount of SOD in blood serum was reported in HF-fed animals, however, liver and brain SOD activity were reduced in the normal fed diet animals followed by HF. GSH-Px of blood serum was observed highest (399.14 U) in $40 \%$ walnut consumption along with HF-diet followed by normal group, however, the lowest in $30 \%$ walnut consumption. In liver and brain, the lowest GSH-Px activity was reported in normal group of animals (241.01 and 24.03 U) respectively followed by HF group. The maximum amount of GSH-Px activity in liver and brain was observed among the group of 40\% walnut consumption (613.65 and $117.48 \mathrm{U}$ ) respectively. Meanwhile, the GSH-Px activity in $\mathrm{HF}, 10 \%$ and $20 \%$ walnut consumption did not show any significant difference to each other at ( $\mathrm{x} \leq 0.05)$ in liver sample. The group of (normal and HF) diet animals was also non-significant to each other. In conclusion to the indicated results the enzymatic anti-oxidant (SOD, GSH-Px) activity is increased with increasing walnut consumption in high fat fed animal and lower in HF-fed animals, it could be due to the presence of more free radicals [35]. Enzymatic reactions, SOD converts superoxide anions $\left(\mathrm{O}_{2}^{-}\right)$to hydrogen peroxide $\left(\mathrm{H}_{2} \mathrm{O}_{2}\right)$, and therefore hydrogen peroxide could be degraded promptly by catalase and GSH-Px to $\mathrm{H}_{2} \mathrm{O}$ [36]. In the previous study, it has been reported that gallic acid leads to a reduction in body weight gain and hepatic oxidative stress by increasing the action of the GSH-Px enzyme that re-claims peroxides in animals of high fat intake [37].

Lipid peroxidation: The melondialdehyde (MDA) of blood serum, liver and brain has been articulated in Table 6. In blood serum, MDA content of normal diet group was shown the lowest $(5.82 \mathrm{nmol} / \mathrm{ml})$ followed by HF-diet along with $40 \%$ consumption and significantly different at $(\mathrm{p} \leq 0.05)$, while highest $(13.83$ $\mathrm{nmol} / \mathrm{ml}$ ) was in $20 \%$ walnut consumption. In the liver, the group of animal fed

Table 6. Lipid peroxidation in blood, liver and brain.

\begin{tabular}{cccc}
\hline & Blood $(\mathrm{nmol} / \mathrm{ml})$ & Liver $(\mathrm{nmol} / \mathrm{mg}$ prot $)$ & Brain (nmol/mg prot) \\
\hline Control & $5.8233^{\mathrm{d}} \pm 0.96$ & $7.3617^{\mathrm{b}} \pm 2.25$ & $3.0100^{\mathrm{b}} \pm 1.29$ \\
High Fat & $9.2167^{\mathrm{bc}} \pm 3.5$ & $6.4400^{\mathrm{b}} \pm 3.4$ & $3.6100^{\mathrm{b}} \pm 3.01$ \\
WF 10\% & $11.727^{\mathrm{ab}} \pm 1.3$ & $6.4233^{\mathrm{b}} \pm 3.22$ & $4.2883^{\mathrm{ab}} \pm 1.59$ \\
WF 20\% & $13.838^{\mathrm{a}} \pm 2.9$ & $9.0967^{\mathrm{ab}} \pm 2.8$ & $6.0483^{\mathrm{a}} \pm 1.17$ \\
WF 30\% & $11.267^{\mathrm{ab}} \pm 1.9$ & $11.180^{\mathrm{a}} \pm 2.5$ & $4.6000^{\mathrm{ab}} \pm 1.15$ \\
WF 40\% & $7.8167^{\mathrm{cd}} \pm 1.5$ & $7.8300^{\mathrm{ab}} \pm 3.1$ & $3.1217^{\mathrm{b}} \pm 0.89$ \\
\hline
\end{tabular}

Mean \pm Standard deviation $(n=6)$ values with the different superscripts with in the column were significant at $(\mathrm{p} \leq 0.05)$. 
by normal, $\mathrm{HF}$ and $10 \%$ walnut showed lowest MDA content $(7.36,6.44$ and $6.42 \mathrm{nmol} / \mathrm{mg}$ protein) and have not significant difference, however, the highest MDA content (11.18 nmol/mg protein) was observed in 30\% walnut intake. Whereas the maximum $(6.04 \mathrm{nmol} / \mathrm{mg}$ protein) MDA content in the brain was observed in $20 \%$ walnut intake followed by group of $30 \%$ walnut intake group (4.6 nmol/mg protein). However the group of normal, HF and $40 \%$ walnut intake animals showd no significant difference to each other and results were expressed as 3.01, 3.6, $3.12 \mathrm{nmol} / \mathrm{mg}$ protein respectively. In this present MDA assay results indicated that lipid peroxidation in normal fed diet and HF-diet have no significant difference and show minimum lipid peroxidation, meanwhile lipid peroxidation is significantly increased by $10 \%-30 \%$ walnut intake, but at $40 \%$ walnut intake the lipid peroxidation significantly decreased in blood serum, liver and brain of rats. In oxidative stress antioxidant activities and lipid peroxidation vital indicator, however, increasing lipid peroxidation could be due to the production of free radicals especially in MUFA [38]. Meanwhile, cell increased the lipid peroxidation due to walnut consumption the animals defends itself against the oxidative stress by elevating the enzymatic antioxidant (SOD, GSH-Px) activity as a safety measure. According to [39] [40], walnut-enriched diet can decrease the MDA concentration.

\section{Conclusion}

In this present study, the results obtained that the fortification of wheat flour with walnut powder up to $40 \%$ walnut substitution could be enriched significantly with protein and fat content. However, due to maximum fat content, proper storage condition needs to avoid the rancidity. The viscoelastic attributes (G" and G') and pasting properties of flour composites had reduced, however, results still within the range and could be used for product processing up to $40 \%$ walnut flour. We have demonstrated that the intake of walnut in a high fed animal could improve the lipid profile by reducing the amount of LDL-C, while HDL-C amount increased. Walnut has unique enzymatic anti-oxidant activity which is useful to improve the oxidative stress such as superoxide dismutase (SOD), glutathione peroxidase (GSH-Px) and lipid peroxidation (MDA) by modifying anti-oxidant defense system and could prevent the risk of obesity and heart-related diseases. Further studies need to conclude that if the larger amount and longtime walnuts consumption linked with improving lipid profile, oxidative stress and lipid peroxidation can be sustained for a long time and diminish clinical points.

\section{Acknowledgements}

This work was supported by the National High Technology Research and Development Program of China (863 Program) (Grant no. 2013AA102206-2).

\section{Conflicts of Interest}

The authors declare no conflicts of interest regarding the publication of this paper. 


\section{References}

[1] Lajolo, F.M. (2002) Functional Foods: Latin American Perspectives. British Journal of Nutrition, 88, S145-S150. https://doi.org/10.1079/BJN2002679

[2] Chen, Z.Y., Ma, K.Y., Liang, Y., Peng, C. and Zuo, Y. (2011) Role and Classification of Cholesterol-Lowering Functional Foods. Journal of Functional Foods, 3, 61-69. https://doi.org/10.1016/j.jff.2011.02.003

[3] Davis, L., Stonehouse, W., Mukuddem-Petersen, J., van der Westhuizen, F.H., Hanekom, S.M. and Jerling, J.C. (2007) The Effects of High Walnut and Cashew Nut Diets on the Antioxidant Status of Subjects with Metabolic Syndrome. European Journal of Nutrition, 46, 155-164. https://doi.org/10.1007/s00394-007-0647-x

[4] US Food and Drug Administration (2003) Qualified Health Claims: Letter of Enforcement Discretion Nuts and Coronary Heart Disease. US Food and Drug Administration, Rockville, 1-4.

[5] Mexis, S.F., Badeka, A.V., Riganakos, K.A., Karakostas, K.X. and Kontominas, M.G. (2009) Effect of Packaging and Storage Conditions on Quality of Shelled Walnuts. Food Control, 20, 743-751. https://doi.org/10.1016/j.foodcont.2008.09.022

[6] Offia-Olua, B.I. (2014) Chemical, Functional and Pasting Properties of Wheat (Triticumspp)-Walnut (Juglansregia) Flour. Food and Nutrition Sciences, 5, 1591. https://doi.org/10.4236/fns.2014.516172

[7] Uchida, K. (2000) Role of Reactive Aldehyde in Cardiovascular Diseases. Free Radical Biology and Medicine, 28, 1685-1696. https://doi.org/10.1016/S0891-5849(00)00226-4

[8] Ceconi, C., Boraso, A., Cargnoni, A. and Ferrari, R. (2003) Oxidative Stress in Cardiovascular Disease: Myth or Fact? Archives of Biochemistry and Biophysics, 420, 217-221. https://doi.org/10.1016/j.abb.2003.06.002

[9] Sohal, R.S., Mockett, R.J. and Orr, W.C. (2002) Mechanisms of Aging: An Appraisal of the Oxidative Stress Hypothesis 1, 2. Free Radical Biology and Medicine, 33, 575-586. https://doi.org/10.1016/S0891-5849(02)00886-9

[10] Hayyan, M., Hashim, M.A. and Alnashef, I.M. (2016) Superoxide Ion: Generation and Chemical Implications. Chemical Reviews, 116, 3029-3085. https://doi.org/10.1021/acs.chemrev.5b00407

[11] Flores-Mateo, G., Navas-Acien, A., Pastor-Barriuso, R. and Guallar, E. (2006) Selenium and Coronary Heart Disease: A Meta-Analysis. The American Journal of Clinical Nutrition, 84, 762-773. https://doi.org/10.1093/ajcn/84.4.762

[12] Iwe, M.O. (2002) Handbook of Sensory Methods and Analysis. Rojoint Communication Services Ltd., Enugu, 7-12.

[13] AOAC (1990) Official Method of Analysis Association of Official Analytical Chemists. 15th Edition, AOAC International Publisher, Washington DC.

[14] Ikegwu, O.J., Nwobasi, V.N., Odoh, M.O. and Oledinma, N.U. (2009) Evaluation of the Pasting and Some Functional Properties of Starch Isolated from Some Improved Cassava Varieties in Nigeria. African Journal of Biotechnology, 8, 2310-2315.

[15] Xiong, Y.L. (1992) A Comparison of the Rheological Characteristics of Different Fractions of Chicken Myofibrillar Proteins 1. Journal of Food Biochemistry, 16, 217-227. https://doi.org/10.1111/j.1745-4514.1992.tb00447.x

[16] Kim, A., Chiu, A., Barone, M.K., Avino, D., Wang, F., Coleman, C.I. and Phung, O.J. (2011) Green Tea Catechins Decrease Total and Low-Density Lipoprotein Cholesterol: A Systematic Review and Meta-Analysis. Journal of the American Dietetic Associa- 
tion, 111, 1720-1729. https://doi.org/10.1016/j.jada.2011.08.009

[17] Kuo, K.L., Weng, M.S., Chiang, C.T., Tsai, Y.J., Lin-Shiau, S.Y. and Lin, J.K. (2005) Comparative Studies on the Hypolipidemic and Growth Suppressive Effects of Oolong, Black, Pu-Erh, and Green Tea Leaves in Rats. Journal of Agricultural and Food Chemistry, 53, 480-489. https://doi.org/10.1021/jf049375k

[18] Eddy, N.O., Udofia, P.G. and Eyo, D. (2007) Sensory Evaluation of Wheat/Cassava Composite Bread and Effect of Label Information on Acceptance and Preference. African Journal of Biotechnology, 6, 2415-2418. https://doi.org/10.5897/AJB2007.000-2379

[19] Sze-Tao, K.W.C. and Sathe, S.K. (2000) Walnuts (Juglans regia L.): Proximate Composition, Protein Solubility, Protein Amino Acid Composition and Protein in Vitro Digestibility. Journal of the Science of Food and Agriculture, 80, 1393-1401. https://doi.org/10.1002/1097-0010(200007)80:9<1393::AID-JSFA653>3.0.CO;2-F

[20] Kolapo, A.L. and Sanni, M.O. (2005) Processing and Characteristics of Soybean-Fortified Tapioca. Journal of Women in Technical Education, 4, 59-66.

[21] Wallace, H.M. and Walton, D.A. (2011) Macadamia (Macadamia integrifolia, Macadamia tetraphylla and Hybrids). In: Yahia, E.M., Ed., Postharvest Biology and Technology of Tropical and Subtropical Fruits. Cocona to Mango, Springer, Berlin, 450-474. https://doi.org/10.1533/9780857092885.450

[22] Jimoh, K.O. and Olatidoye, O.P. (2009) Evaluation of Physicochemical and Rheological Characteristics of Soybean Fortified Yam Flour. Journal of Applied Biosciences, 13, 703-706.

[23] Radley, J.A. (2012) Examination and Analysis of Starch and Starch Products. Springer Science \& Business Media, Berlin.

[24] Rouillé, J., Della Valle, G., Lefebvre, J. and Sliwinski, E. (2005) Shear and Extensional Properties of Bread Doughs Affected by Their Minor Components. Journal of Cereal Science, 42, 45-57. https://doi.org/10.1016/j.jcs.2004.12.008

[25] Kurimoto, Y. and Shelton, D.R. (1988) The Effect of Flour Particle Size on Baking Quality and Other Flour Attributes. Cereal Foods World, 38, 429-438.

[26] Banel, D.K. and Hu, F.B. (2009) Effects of Walnut Consumption on Blood Lipids and Other Cardiovascular Risk Factors: A Meta-Analysis and Systematic Review. The American Journal of Clinical Nutrition, 90, 56-63. https://doi.org/10.3945/ajcn.2009.27457

[27] Sabaté, J., Cordero-MacIntyre, Z., Siapco, G., Torabian, S. and Haddad, E. (2005) Does Regular Walnut Consumption Lead to Weight Gain? British Journal of Nutrition, 94, 859-864. https://doi.org/10.1079/BJN20051567

[28] Garcia-Lorda, P., Rangil, I.M. and Salas-Salvado, J. (2003) Nut Consumption, Body Weight and Insulin Resistance. European Journal of Clinical Nutrition, 57, S8. https://doi.org/10.1038/sj.ejcn.1601802

[29] Luo, M., Mengos, A.E., Stubblefield, T.M. and Mandarino, L.J. (2012) High Fat Diet-Induced Changes in Hepatic Protein Abundance in Mice. Journal of Proteomics and Bioinformatics, 5, 60-66. https://doi.org/10.4172/jpb.1000214

[30] Iwamoto, M., Imaizumi, K., Sato, M., Hirooka, Y., Sakai, K., Takeshita, A. and Kono, M. (2002) Serum Lipid Profiles in Japanese Women and Men during Consumption of Walnuts. European Journal of Clinical Nutrition, 56, 629. https://doi.org/10.1038/sj.ejcn.1601400

[31] Morgan, J., Horton, K., Reese, D., Carey, C., Walker, K. and Capuzzi, D. (2002) Effects of Walnut Consumption as Part of a Low-Fat, Low-Cholesterol Diet on Serum 
Cardiovascular Risk Factors. International Journal for Vitamin and Nutrition Research, 72, 341-347. https://doi.org/10.1024/0300-9831.72.5.341

[32] Cintra, D.E., Costa, A.V., Maria do Carmo, G.P., Matta, S.L., Silva, M.T.C. and Costa, N.M. (2006) Lipid Profile of Rats Fed High-Fat Diets Based on Flaxseed, Peanut, Trout, or Chicken Skin. Nutrition, 22, 197-205. https://doi.org/10.1016/j.nut.2005.09.003

[33] Jenkinson, A., Franklin, M.F., Wahle, K. and Duthie, G.G. (1999) Dietary Intakes of Polyunsaturated Fatty Acids and Indices of Oxidative Stress in Human Volunteers. European Journal of Clinical Nutrition, 53, 523. https://doi.org/10.1038/sj.ejcn.1600783

[34] Fukuda, T., Ito, H. and Yoshida, T. (2003) Antioxidative Polyphenols from Walnuts (Juglans regia L.). Phytochemistry, 63, 795-801. https://doi.org/10.1016/S0031-9422(03)00333-9

[35] Rocha, K.K.R., Souza, G.A., Ebaid, G.X., Seiva, F.R.F., Cataneo, A.C. and Novelli, E.L.B. (2009) Resveratrol Toxicity: Effects on Risk Factors for Atherosclerosis and Hepatic Oxidative Stress in Standard and High-Fat Diets. Food and Chemical Toxicology, 47, 1362-1367. https://doi.org/10.1016/j.fct.2009.03.010

[36] Lee, S.J., Choi, S.K. and Seo, J.S. (2009) Grape Skin Improves Antioxidant Capacity in Rats Fed a High Fat Diet. Nutrition Research and Practice, 3, 279-285. https://doi.org/10.4162/nrp.2009.3.4.279

[37] Hsu, C.L. and Yen, G.C. (2007) Effect of Gallic Acid on High Fat Diet-Induced Dyslipidaemia, Hepatosteatosis and Oxidative Stress in Rats. British Journal of Nutrition, 98, 727-735. https://doi.org/10.1017/S000711450774686X

[38] Cetinkaya, A., Kurutas, E.B., Buyukbese, M.A., Kantarceken, B. and Bulbuloglu, E. (2005) Levels of Malondialdehyde and Superoxide Dismutase in Subclinical Hyperthyroidism. Mediators of Inflammation, 2005, 57-59. https://doi.org/10.1155/MI.2005.57

[39] Canales, A., Benedí, J., Nus, M., Librelotto, J., Sánchez-Montero, J.M. and Sánchez-Muniz, F.J. (2007) Effect of Walnut-Enriched Restructured Meat in the Antioxidant Status of Overweight/Obese Senior Subjects with at Least One Extra CHD-Risk Factor. Journal of the American College of Nutrition, 26, 225-232. https://doi.org/10.1080/07315724.2007.10719605

[40] Nus, M., Frances, F., Librelotto, J., Canales, A., Corella, D., Sánchez-Montero, J.M. and Sánchez-Muniz, F.J. (2007) Arylesterase Activity and Antioxidant Status Depend on PON1-Q192R and PON1-L55M Polymorphisms in Subjects with Increased Risk of Cardiovascular Disease Consuming Walnut-Enriched Meat. The Journal of Nutrition, 137, 1783-1788. https://doi.org/10.1093/jn/137.7.1783 